\title{
Organization of Individual Work of Students in Blended Learning of Foreign Languages at Higher Educational Institutions
}

\author{
Bohdana V. Avramenko \\ South Ukrainian National Pedagogical University Named After K.D. Ushynsky \\ Olena A. Buzdugan \\ South Ukrainian National Pedagogical University Named After K.D. Ushynsky \\ Inna L. Myrkovich \\ South Ukrainian National Pedagogical University Named After K.D. Ushynsky \\ Nataliia O. Oskina \\ South Ukrainian National Pedagogical University Named After K.D. Ushynsky \\ Eleonora Stryga \\ South Ukrainian National Pedagogical University Named After K.D. Ushynsky
}

The purpose of the academic paper is as follows: to evaluate the effectiveness of individual work of students in blended learning of foreign languages at higher educational institutions in order to identify problems and prospects for autonomous learning. Methodology. The paper uses the online form of the questionnaire to conduct a survey of 260 students of Ukrainian universities in September-October 2020. The results demonstrate several important conclusions. Social-demographic characteristics of students affect the effectiveness of self-organization of students in the study of foreign languages with application of technologies. The basic problems of individual work of students in blended learning of foreign languages at HEI are determined as follows: technical and the need for support from a technical specialist; inconvenience of a blended learning system; the need for additional technical skills; the complexity of blended learning. The effectiveness of the learning process based on the system and technologies of blended learning has been also assessed at the average level.

Keywords: students' autonomy, self-organization, communication, educational skills, information

\section{INTRODUCTION}

Blended learning (BL) is in progress due to the limited study time of students, the development of professional competencies in the context of foreign languages proficiency. The term has been used since at least 2007 (Hockly, 2018), and the direction of education itself has been actively developing for the last ten years. BL assumes a special organization of students' work, where methods of personal communication 
and interactive cooperation through information and communication technologies (ICT) are combined (Ju, 2018), which provides for the autonomy of students (Hubackova and Semradova, 2016). BL performs several functions, namely: preparation for the formation of constructive and algorithmic thinking of students, improving the quality of teaching, the implementation of the social order (Ju, 2018), development of professional and information competencies of students (Nazarenko, 2015), increasing the level of motivation to learn foreign languages (Banditvilai, 2016; Arkhipova et al., 2017), development of language skills (Banditvilai, 2016). "Blended learning" is the term most commonly used to refer to any combination of "face-to-face" (Hockly, 2018).

The effectiveness of the organization of independent work of students in blended learning is determined by such factors, as: the level of preparation of students for online learning and work in a virtual environment; the quality of the virtual environment; the ability to self-organize and work autonomously; the use of BL tools (Hubackova and Semradova, 2016). In the scientific literature, students' feedback on autonomous work in blended learning of foreign languages has been little studied, which makes it difficult to assess the success of this approach. The authors make their own reflective assessments of BL in order to summarize the reaction of students (Tomlinson and Whittaker, 2013). Some investigations (Nazarenko, 2015) have studied the subjective reaction of students to the problems of using the BL approach in order to study the prerequisites for integrating this direction of education. The purpose of the academic paper is to evaluate the effectiveness of individual work of students in blended learning of foreign languages at higher educational institutions in order to identify problems and prospects for autonomous learning.

The basic hypotheses of the study are defined as follows:

Hypothesis 1. Students of 3-4 courses have a higher level of self-organization and autonomy in work in blended learning of foreign languages.

Hypothesis 2. There is a difference in the level of self-organization and autonomy of male and female students in blended learning of foreign languages.

Hypothesis 3. Social-demographic characteristics determine the level of autonomy and individual work of students in blended learning of foreign languages at higher educational institutions.

\section{LITERATURE REVIEW}

BL is considered as an approach to learning (Nazarenko, 2015), the concept (Grasl et al., 2012; Buran and Evseeva, 2015), the direction of education and studying foreign languages (Tomlinson and Whittaker, 2013), the way students organize their work (Ju, 2018), system of interaction between teachers and students during studying foreign languages (Shaidullin et al., 2014; Wang et al., 2015; Hockly, 2018), methodology of teaching foreign languages (Hubackova and Semradova, 2016; Banditvilai, 2016), an effective tool for learning foreign languages (Arkhipova et al., 2017), technology for learning foreign languages (Shaidullin et al., 2014; Schober et al., 2008). Paradigm, the concept of blended learning in person-centered e-learning aims at intellectual, social and personal development by combining the benefits of online learning with face-to-face meetings (Motschnig-Pitrik and Mallich, 2004). The added value of person-centered blended learning lies in increasing confidence, motivation and interpersonal communication skills (MotschnigPitrik and Mallich, 2004). Interpersonal relationships in the process of blended learning significantly affect students' motivation and students' learning outcomes (Motschnig-Pitrik and Mallich, 2004). Herewith, the prospects and potential of web support for improving the effectiveness of individual-oriented learning are little discussed in the scientific literature.

BL provides a transition from a teacher-centered approach to foreign language teaching to a studentcentered approach (Wan and Niu, 2018). In addition, recent investigations prove the integration of a student-centered approach (Bodnar, 2021) based on systems self-organization theory. In this context, the concept of students' autonomy is relevant. "Autonomy can be considered as a necessary condition, in which a student uses endless potential of a human brain and modern technologies, including information ones, to 
attain knowledge faster, with higher efficiency and less effort" (Ju, 2018; Pohrishchuk and Voloshchuk, 2021). The ability to self-organize the work of students is an important factor in the effectiveness of BL (Hubackova and Semradova, 2016). "Online practice is directly beneficial to enhance the four language learning skills as well as autonomous learning and learners' motivation” (Banditvilai, 2016).

The following basic problems of BL have been revealed in the scientific literature, namely: 1) technical, 2) strict terms of performance of tasks; 3) lack of time to track students' work (Buran and Evseeva, 2015); 4) too many tasks; 5) watching videos of lectures at home prior coming to class; 6) unfamiliar interface; 7) the need for adaptation and the time spent on adaptation; 8) annotation of educational materials/articles; 9) discussion; 10) computer work ("more exhausting than regular classroom work") (Nazarenko, 2015). In the process of using blended learning technologies, the following models have been formed depending on the component, namely: 1) component of the traditional direct personal interaction of participants in the educational process; 2) component of interactive communication mediated by computer telecommunication technologies and electronic information and educational Internet resources; 3) component of self-education (Shaidullin et al., 2014; Waitzman et al., 2019; Senne et al., 2020). Traditionally, the following models are distinguished in the practice of foreign countries, namely: "Face-to-Face Driver" Model, "Rotation" Model, "Flex" Model, "Online Lab" Model, "Self-blend" Model, "Online Driver" Model (Table 1).

\section{TABLE 1 BL MODELS}

\begin{tabular}{|l|l|}
\hline Model & Description \\
\hline $\begin{array}{l}\text { "Face-to-Face } \\
\text { Driver" Model }\end{array}$ & $\begin{array}{l}\text { Most of the curriculum is taught directly in interaction with teachers. E-learning is } \\
\text { a supplement to the main traditional program (curriculum); working with e- } \\
\text { resources involves working on computers. }\end{array}$ \\
\hline "Rotation" model & $\begin{array}{l}\text { Teaching hours are divided between individual online learning and traditional } \\
\text { classroom learning with a teacher. The teacher in the classroom provides electronic } \\
\text { support online. }\end{array}$ \\
\hline $\begin{array}{l}\text { "Onlex" Model } \\
\text { model }\end{array}$ & $\begin{array}{l}\text { Most of the curriculum is integrated into online training. The teacher accompanies } \\
\text { the student remotely to study difficult subjects; he provides pieces of advice } \\
\text { individually or for groups. }\end{array}$ \\
\hline $\begin{array}{l}\text { "Self-blend" } \\
\text { model }\end{array}$ & $\begin{array}{l}\text { institutions in classrooms with computers; teachers participate in the learning } \\
\text { process. There is a possibility of traditional training according to a fixed system. }\end{array}$ \\
\hline $\begin{array}{l}\text { The traditional model of American higher education. Students are autonomous in } \\
\text { choosing additional courses to basic education. Providers of educational content are } \\
\text { various educational institutions. } \\
\text { model }\end{array}$ & $\begin{array}{l}\text { Most of the curriculum involves the development of electronic resources of } \\
\text { information and educational environment. Personal communications with the } \\
\text { teacher are periodic. Procedures for face-to-face consultations, interviews and } \\
\text { examinations are mandatory. }\end{array}$ \\
\hline
\end{tabular}

Source: R.N. Shaidullin, L.N. Safiullin, I.R. Gafurov, N.Z. Safiullin (2014).

The prerequisites for self-organization of students' work in blended learning are also discussed in the scientific literature. 'Self-organizing refers to a system's ability to create its own organization, independent of top-down control, by following a set of simple rules that enables collaboration" (Conway et al., 2011). The following ones are among them, namely: space, knowledge and cooperation (Saray et al., 2021). Knowledge management in the context of a large amount of information is a particularly important prerequisite for the effectiveness of autonomy. 


\section{MATERIALS AND METHODS}

Students should clearly prioritize materials. In addition, the exchange of knowledge within the work of blended learning is an extremely important process. Individual experience of using information and knowledge is important; consequently, practitioners should pass on experience to theorists. Learning is a creative process where students shape course content. The composition of the students' group also influences the learning process, especially in the context of intercultural interaction and students' migration. Space is also an important prerequisite that is often ignored. The learning environment should not be limited to boundaries and frameworks clearly defined by the materials. It is important for students to provide space for the ease of use of the learning environment, including ease of access, defined context, ways of learning, use of social networks as additional space and platform for learning. Technologies should be a means of implementation for the storage, distribution, organization of interaction and knowledge.

Cooperation falls within two preconditions. The learning process is a socially complex process of selforganization of subjects who behave unpredictably. These subjects (persons) form groups with different characteristics (age, gender, nationality, culture) and behavior. Teamwork or group work often transforms the process of blended learning through personal contribution to the development of individual processes. In fact, it confirms the idea that learning is a creative process. Thus, the advantages and disadvantages, prerequisites, components and models of blended learning in various spheres of life are actively discussed in the scientific literature. Herewith, the issue of the effectiveness of individual work of students in blended learning of foreign languages at higher educational institutions is little studied.

This study is based on the theory of self-organization in the context of the autonomy of students in mixed learning of foreign languages at higher educational institutions. The academic paper has used the online form of the questionnaire in order to conduct a survey of students of Ukrainian universities in September-October 2020. The structured interview as a research method included 24 questions: 1) on the effectiveness of the organization of the system and technologies of blended learning (questions 1-10); 2) on the effectiveness of the educational process based on the system and technologies of blended learning (questions 11-20); 3) questions about age, gender and course of study (Table 3). Students assessed statements 1-10 from 1 to 4, where 1 - strongly disagree, 4 - strongly agree; statements 11-20 from 1 to 5, where 1 - strongly disagree, 5 - strongly agree. 260 students of the HEI of Ukraine of various specialties took part in the survey (Table 2). Among all respondents, $41.4 \%$ are 2 nd year students, $13.8 \%$ are 3 rd year students, $41.4 \%$ are 4 th year students and $3.4 \%$ are 5 th year students. $44.8 \%$ of respondents are male and $55.2 \%$ female, $62.1 \%$ aged $18-20$ years old and $37.9 \%$ aged $21-22$ years old.

TABLE 2

DESCRIPTIVE STATISTICS OF SURVEY DATA

\begin{tabular}{|l|c|c|c|}
\hline & Course of Study & Sex* & Age** \\
\hline Average value & 3.069 & 1.5517 & 1.3793 \\
\hline Median & 3.000 & 2.0000 & 1.0000 \\
\hline Standard deviation & .9975 & .50612 & .49380 \\
\hline Dispersion & .995 & .256 & .244 \\
\hline Minimum & 2.0 & 1.00 & 1.00 \\
\hline Maximum & 5.0 & 2.00 & 2.00 \\
\hline
\end{tabular}

Note: * 1-male, 2 -female; $* * 1-$ age $18-20$ years old and 2 -age 21-22 years old.

Source: calculated by the authors.

The following statistical methods of processing the survey results have been used in the study, namely:

1. Pearson's Chi-Square Test of Independence in order to determine the impact of socialdemographic characteristics of students on the level of self-organization and autonomy of students. The value of Pearson's statistics and the level of significance have been used to draw conclusions about the presence or absence of influence. 
2. Mean and Standard deviation have been used to determine the differences between the level of self-organization and autonomy of students depending on gender.

3. Independent Sample T-test has been used to determine the differences in the level of selforganization and autonomy of students depending on gender (Table 3).

TABLE 3

SURVEY ON THE EFFECTIVENESS OF THE BLENDED LEARNING SYSTEM (QUESTIONS 1-10) AND THE LEARNING PROCESS BASED ON THE BLENDED LEARNING SYSTEM AND TECHNOLOGIES (QUESTIONS 11-20)

\begin{tabular}{|c|c|c|c|c|c|c|}
\hline \multirow[t]{2}{*}{ No. } & \multirow[t]{2}{*}{ Statement } & \multicolumn{5}{|c|}{ Grade } \\
\hline & & 1 & 2 & 3 & 4 & 5 \\
\hline 1 & I think I would like to use the blended learning system in the future & & & & & \\
\hline 2 & I find blended learning difficult & & & & & \\
\hline 3 & I thought the web learning system was easy to use & & & & & \\
\hline 4 & I need the support of a technician to use blended learning technologies & & & & & \\
\hline 5 & $\begin{array}{l}\text { The various functions of blended learning are successfully integrated and } \\
\text { interact with each other }\end{array}$ & & & & & \\
\hline 6 & There are many inconsistencies in blended learning & & & & & \\
\hline 7 & Blended learning technologies can be learned quickly & & & & & \\
\hline 8 & The system is not easy to use & & & & & \\
\hline 9 & I felt confident while using technology & & & & & \\
\hline 10 & I needed additional skills prior I started using technology & & & & & \\
\hline 11 & $\begin{array}{l}\text { The goals of learning a foreign language were understood and defined in the } \\
\text { system of blended learning }\end{array}$ & & & & & \\
\hline 12 & $\begin{array}{l}\text { The process of organizing work in the blended learning system was well } \\
\text { organized }\end{array}$ & & & & & \\
\hline 13 & The material is presented interestingly; it is easily accessible & & & & & \\
\hline 14 & There were enough videos, examples and illustrations in the system & & & & & \\
\hline 15 & Concepts, materials and ideas were understandable and clearly presented & & & & & \\
\hline 16 & The duration of training was sufficient for learning a foreign language & & & & & \\
\hline 17 & The training expanded my professional and communication skills & & & & & \\
\hline 18 & I can use the acquired knowledge in professional activities & & & & & \\
\hline 19 & Blended learning is as effective as traditional methods & & & & & \\
\hline 20 & $\begin{array}{l}\text { I am satisfied with the organization of work and the level of autonomy in } \\
\text { learning a foreign language }\end{array}$ & & & & & \\
\hline 21 & Your age & & & & & \\
\hline 22 & Gender & & & & & \\
\hline 23 & Course of Study & & & & & \\
\hline
\end{tabular}

\section{RESULTS}

Blended learning has become actively used in Ukraine with the spread of coronavirus; universities are actively integrating technologies and platforms into the educational process. Moodle is among the most common platforms for the exchange of materials between a teacher and a student; it provides lectures in electronic form, homework, automatic monitoring of tasks, assessment. Additional technologies of blended learning are Zoom, Microsoft Teams, Viber, which provide communication between a teacher and a student. Descriptive statistics of the results of students' structured interviews indicate the average level of satisfaction with the technology and system of blended learning (Table 4). The average value ranges from 1.897 to 3.207 with significant deviations. 
TABLE 4

DESCRIPTIVE STATISTICS

\begin{tabular}{|c|c|c|c|c|}
\hline & Minimum & Maximum & $\begin{array}{l}\text { Average } \\
\text { value }\end{array}$ & $\begin{array}{l}\text { Standard } \\
\text { deviation }\end{array}$ \\
\hline $\begin{array}{l}\text { I think I would like to use the blended } \\
\text { learning system in the future }\end{array}$ & 1.0 & 4.0 & 2.724 & 1.1618 \\
\hline I find blended learning difficult & 1.0 & 4.0 & 2.276 & 1.0986 \\
\hline $\begin{array}{l}\text { I thought the web learning system was easy } \\
\text { to use }\end{array}$ & 1.0 & 4.0 & 3.207 & .7736 \\
\hline $\begin{array}{l}\text { I need the support of a technician to use } \\
\text { blended learning technologies }\end{array}$ & 1.0 & 4.0 & 1.897 & 1.0805 \\
\hline $\begin{array}{l}\text { The various functions of blended learning } \\
\text { are successfully integrated and interact with } \\
\text { each other }\end{array}$ & 1.0 & 4.0 & 2.966 & .8653 \\
\hline $\begin{array}{l}\text { There are many inconsistencies in blended } \\
\text { learning }\end{array}$ & 1.0 & 4.0 & 2.552 & 1.2126 \\
\hline $\begin{array}{l}\text { Blended learning technologies can be } \\
\text { learned quickly }\end{array}$ & 1.0 & 4.0 & 3.034 & 1.1175 \\
\hline The system is not easy to use & 1.0 & 4.0 & 2.172 & 1.1973 \\
\hline I felt confident while using technology & 1.0 & 4.0 & 3.000 & .9258 \\
\hline $\begin{array}{l}\text { I needed additional skills prior I started } \\
\text { using technology }\end{array}$ & 1.0 & 4.0 & 2.276 & 1.1306 \\
\hline $\begin{array}{l}\text { The goals of learning a foreign language } \\
\text { were understood and defined in the system } \\
\text { of blended learning }\end{array}$ & 1.0 & 5.0 & 3.690 & 1.3121 \\
\hline $\begin{array}{l}\text { The process of organizing work in the } \\
\text { blended learning system was well } \\
\text { organized }\end{array}$ & 1.0 & 5.0 & 3.690 & 1.1681 \\
\hline $\begin{array}{l}\text { The material is presented interestingly; it is } \\
\text { easily accessible }\end{array}$ & 1.0 & 5.0 & 3.345 & 1.3437 \\
\hline $\begin{array}{l}\text { There were enough videos, examples and } \\
\text { illustrations in the system }\end{array}$ & 1.0 & 5.0 & 3.276 & 1.3335 \\
\hline $\begin{array}{l}\text { Concepts, materials and ideas were } \\
\text { understandable and clearly presented }\end{array}$ & 1.0 & 5.0 & 3.621 & 1.2653 \\
\hline $\begin{array}{l}\text { The duration of training was sufficient for } \\
\text { learning a foreign language }\end{array}$ & 1.0 & 5.0 & 3.552 & 1.2702 \\
\hline $\begin{array}{l}\text { The training expanded my professional and } \\
\text { communication skills }\end{array}$ & 1.0 & 5.0 & 3.414 & 1.4272 \\
\hline $\begin{array}{l}\text { I can use the acquired knowledge in } \\
\text { professional activities }\end{array}$ & 1.0 & 5.0 & 3.517 & 1.3528 \\
\hline $\begin{array}{l}\text { Blended learning is as effective as } \\
\text { traditional methods }\end{array}$ & 1.0 & 5.0 & 3.172 & 1.3905 \\
\hline $\begin{array}{l}\text { I am satisfied with the organization of work } \\
\text { and the level of autonomy in learning a } \\
\text { foreign language }\end{array}$ & 1.0 & 5.0 & 3.379 & 1.4979 \\
\hline
\end{tabular}

Source: calculated by the authors.

The most common problems of using blended learning technologies are as follows: technical and the need for technical support; the inconvenience of a blended learning system; the need for additional technical 
skills; the complexity of blended learning. Thus, on the one hand, there is a problem on the part of the university in ensuring the quality of technical characteristics of platforms and systems of blended learning; on the other hand, there is no sufficient level of digital skills of students (Berzina, 2019). This requires the development of video instructions for the use of blended learning technologies. At the same time, students note the potential of using blended learning, ease of use, successful integration of different functions and their interaction; speed of learning in the use of blended learning technologies. The effectiveness of the learning process based on the system and technologies of blended learning is also assessed at the average level: grades range from 3.172 to 3.690. Among the biggest problems the following ones should be noted, namely: unclear goals of using a blended learning system; organization of the blended learning process; ease and simplicity of presentation of material; lack of examples and illustrative material; lack of time to study materials; expansion of professional and communication skills (Figure 1).

\section{FIGURE 1 \\ PROBLEMS OF EFFECTIVE ORGANIZATION OF INDIVIDUAL WORK OF STUDENTS IN BLENDED LEARNING}

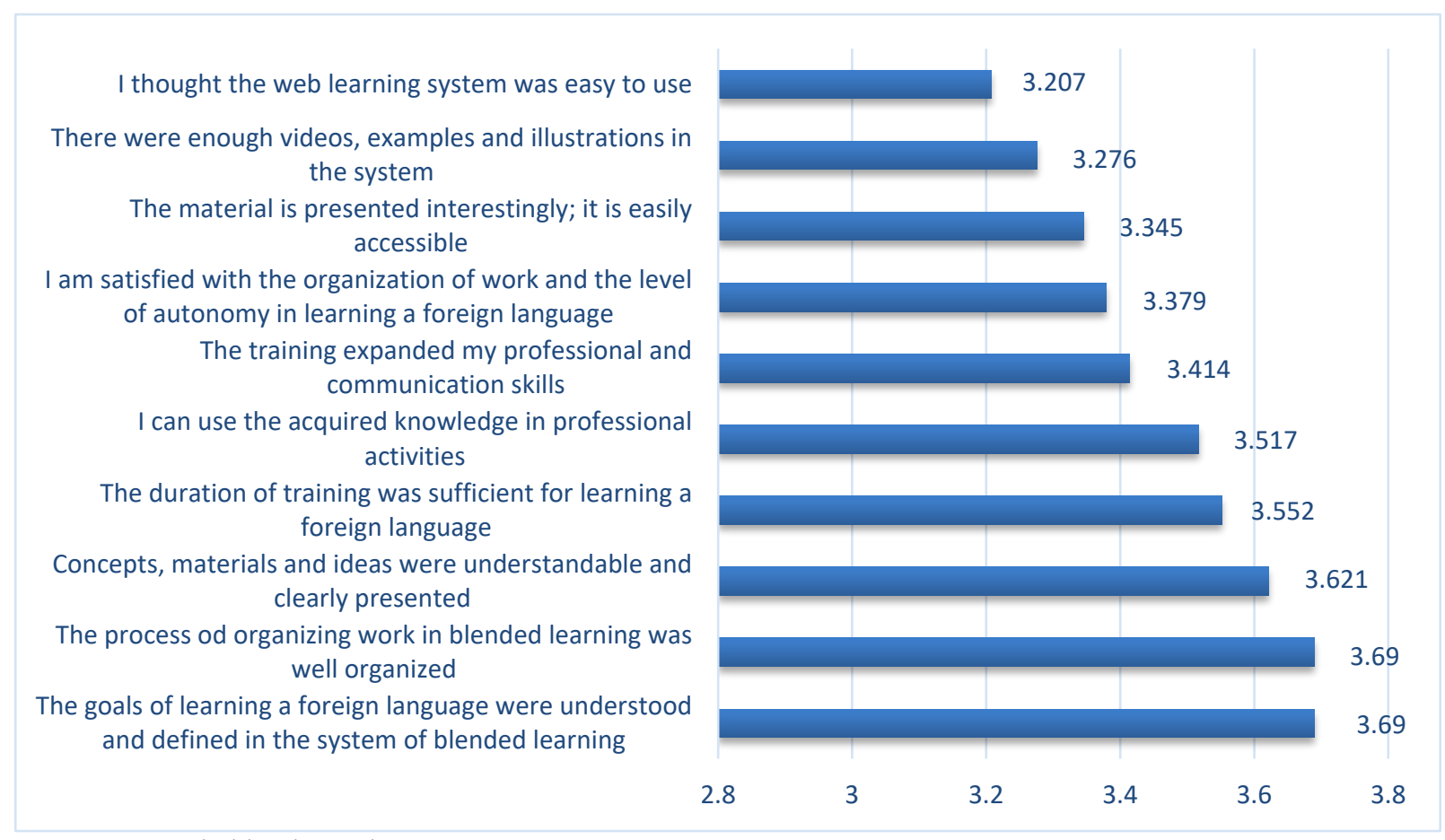

Source: compiled by the authors.

The level of satisfaction with the organization of work and the level of autonomy in learning a foreign language averages 3.379. Thus, the organization of students' work is not autonomous enough. In order to study in detail, the reasons for the average level of self-organization, it is advisable to conduct a Chi-Square Test of Independence for determining the relationship between social-demographic characteristics of students and the level of autonomy (Table 5). Hypothesis 1. Students of 3-4 courses have a higher level of self-organization and autonomy in work in blended learning of foreign languages. 


\section{TABLE 5}

\section{RESULTS OF PEARSON'S CHI-SQUARE TEST OF INDEPENDENCE: COURSE OF STUDY AND LEVEL OF SELF-ORGANIZATION AND AUTONOMY OF STUDENTS' WORK (I NEED THE SUPPORT OF A TECHNICIAN TO USE BLENDED LEARNING TECHNOLOGIES)}

\begin{tabular}{|l|c|c|}
\hline & Value & Sig. (2-tailed) \\
\hline Chi-Square & $19.880^{\mathrm{a}}$ & 0.19 \\
\hline Likelihood ratio & 17.777 & 0.38 \\
\hline Linear connection & 4.276 & 0.39 \\
\hline
\end{tabular}

Source: calculated by the authors.

Forasmuch as the value of Chi-Square is 19.880 and the significance level is 0.019 , it is possible to conclude that there is a statistically significant difference between the levels of autonomy of students depending on the course of study; these variables are significantly interdependent. In order to assess the level of students' autonomy depending on social-economic characteristics (Holiachuk et al., 2020), a ChiSquare Test of Independence was conducted for the variable "Blended learning technologies can be learned quickly" (Table 6). High test values for the variable course of study with a value of p-value $=0.133(\geq 0,05)$ indicate that blended learning technologies take time to develop skills of use regardless of the course. At the same time, age and gender affect the speed of learning the functions of blended learning technologies.

TABLE 6

RESULTS OF PEARSON'S CHI-SQUARE TEST OF INDEPENDENCE: COURSE, AGE AND GENDER AND THE LEVEL OF SELF-ORGANIZATION AND AUTONOMY OF STUDENTS (BLENDED LEARNING TECHNOLOGIES CAN BE LEARNED QUICKLY)

\begin{tabular}{|c|c|c|}
\hline $\begin{array}{l}\text { I believe that most students can learn to use a } \\
\text { blended learning system quickly }\end{array}$ & Value & Sig. (2-tailed) \\
\hline \multicolumn{3}{|c|}{ Course of Study } \\
\hline Chi-Square & 13.706 & 0.133 \\
\hline Likelihood ratio & 17.101 & 0.047 \\
\hline Linear connection & 4.186 & 0.041 \\
\hline \multicolumn{3}{|c|}{ Age } \\
\hline Chi-Square & 7.065 & 0.070 \\
\hline Likelihood ratio & 7.466 & 0.058 \\
\hline Linear connection & 6.387 & 0.011 \\
\hline \multicolumn{3}{|c|}{ Sex } \\
\hline Chi-Square & 6.906 & 0.075 \\
\hline Likelihood ratio & 8.826 & 0.032 \\
\hline Linear connection & 4.793 & 0.029 \\
\hline
\end{tabular}

Source: calculated by the authors.

Hypothesis 2. There is a difference in the level of self-organization and autonomy of male and female students in blended learning of foreign languages. Table 7 makes it possible to conclude that the average need for technical support and a specialist to use a blended learning system is 2.308 for males and 1.688 for females. The standard deviation for males is slightly higher compared to females. 
TABLE 7

GROUP STATISTICS: GENDER AND LEVEL OF SELF-ORGANIZATION AND AUTONOMY OF STUDENTS

\begin{tabular}{|c|c|c|c|c|c|}
\hline & Sex & $\mathrm{N}$ & Mean & $\begin{array}{l}\text { Standard } \\
\text { deviation }\end{array}$ & $\begin{array}{l}\text { Std. Error } \\
\text { Mean }\end{array}$ \\
\hline \multirow{2}{*}{$\begin{array}{l}\text { I need the support of a technician to } \\
\text { use blended learning technologies }\end{array}$} & 1.00 & 13 & 2.308 & 1.3156 & .3649 \\
\hline & 2.00 & 16 & 1.688 & .7042 & .1760 \\
\hline
\end{tabular}

Source: calculated by the authors.

TABLE 8

INDEPENDENT SAMPLE T-TEST

\begin{tabular}{|c|c|c|c|c|c|c|c|c|c|c|}
\hline & \multicolumn{2}{|c|}{$\begin{array}{l}\text { Levene-s } \\
\text { test for } \\
\text { Equality of } \\
\text { variances }\end{array}$} & \multicolumn{7}{|c|}{ t-test for Equality of Means } \\
\hline & & \multirow[t]{2}{*}{$\mathrm{F}$} & \multirow[t]{2}{*}{ Sig. } & \multirow[t]{2}{*}{$\mathrm{t}$} & \multirow[t]{2}{*}{$\mathrm{df}$} & \multirow[t]{2}{*}{$\begin{array}{l}\text { Sig. } \\
\text { (2- } \\
\text { tailed) }\end{array}$} & \multirow[t]{2}{*}{$\begin{array}{c}\text { Mean } \\
\text { difference }\end{array}$} & \multirow[t]{2}{*}{$\begin{array}{l}\text { Std. Error } \\
\text { Difference }\end{array}$} & \multicolumn{2}{|c|}{$\begin{array}{l}\text { 95\% Confidence } \\
\text { Interval of the } \\
\text { difference }\end{array}$} \\
\hline & & & & & & & & & Lower & Upper \\
\hline \multirow{2}{*}{$\begin{array}{l}\text { I need the } \\
\text { support of a } \\
\text { technician } \\
\text { to use } \\
\text { blended } \\
\text { learning } \\
\text { technologies }\end{array}$} & $\begin{array}{l}\text { Equal } \\
\text { variances } \\
\text { assumed }\end{array}$ & 10.94 & .003 & 1.63 & 27 & .116 & .62 & .382 & -.163 & 1.403 \\
\hline & $\begin{array}{l}\text { Equal } \\
\text { variances } \\
\text { not } \\
\text { assumed }\end{array}$ & & & 1.531 & 17.479 & .144 & .620 & .405 & -.233 & 1.473 \\
\hline
\end{tabular}

Source: calculated by the author.

The level of significance ( $p$-value for Levene's test) is 0.003 , which is less than $\alpha=0.05$; consequently, we reject the hypothesis of equality of variation: variation for male and female students is different (Table 8). Therefore, we use line 2 to draw conclusions about the hypothesis of equality of variance: deviations in self-organization and autonomy of students are not equal; t-statistics and its p-values are 1.531 and 0.144 , respectively; therefore, with a probability of error of $5 \%$, we have come to conclusion that there are no differences in the level of self-organization and autonomy of work between male and female students. Thus, the effectiveness of individual work of students in blended learning of foreign languages at HEI is at an average level, which is confirmed by the need of students for technical support, spending time on adapting to platforms and technologies, teaching methods. This causes a number of problems of autonomous learning.

\section{DISCUSSION}

Rapidly changing characteristics of the e-learning environment require the adaptation of students and the integration of the principle of diversity in the process of organizing blended learning (Frankl and Bitter, 2011; Sanjeev and Natrajan, 2019). Recommendations for improving the blended learning process should be adaptive to the external, internal conditions of the learning process. These recommendations are formed by analyzing the learning activities of students and the behavior of self-organization (Wan and Niu, 2018). The findings of this research are partially correlated with the study conducted by A. Buran and A. Evseeva (2015) on the combination of online learning and face-to-face classes as a priority mode of teaching and learning foreign languages in modern conditions. The importance of integrated blended learning is explained by the need for communication skills that can be implemented in an e-learning environment 
(Lopukhova et al., 2019). Students get the opportunity to develop their communication skills through online interaction with each other, discussing problems in forums and chats, performing other actions. In addition, blended learning provides a number of important benefits for teachers and students, making them active participants in the learning process, responsible for the results of their own activities (Grasl et al., 2012). Despite the fact that the development of e-courses in the first stage takes a long time, it makes it possible fot teachers to optimize their time and maintain the quality of the educational process (Hubackova and Semradova, 2016). The proposed mode of study helps meet the new requirements of the educational system, where information technology and the use of Internet resources play a vital role (Voitsikhovskyi et al., 2021).

Among the basic directions of development of blended training courses, the following ones should be highlighted, namely (Hockly, 2018):

1. Interaction: providing online interaction with other students and teachers.

2. Research: integration of principles of adaptability in the process of blended learning.

3. Development of tasks and tools: task development and selection of technological tools.

4. Materials: you can integrate video lectures, blogs and chats instead of providing only content/introduction, forming tasks and materials.

5. Integration: there should be a clear link and integration between $f 2 f$ and the technological components of the course, each of which complements, supports and develops the other.

6. Assessment: work based on technology (including oral and/or written work) should be integrated into students' overall assessment

7. Context: blended learning design should take into account the local context, including the needs, skills, expectations and beliefs of students and teachers.

8. Teachers' training: learning is a key factor for the successful implementation of a blended approach, in order to ensure that teachers understand the basic principles and are able to effectively use blended learning.

9. Students' learning: if students consider the problem of autonomous work, blended learning may require some initial students' training.

The ideal solution to improve the blended learning process is to use the services of a team of developers, designers, programmers and professionals to develop blended learning programs and courses (TemelmanYogev et al., 2020). However, in practice, teachers displace these teams due to the university's limited budget (Hryniak et al., 2021). The teacher is responsible for materials, technical support, assessment, control of students. The main disadvantage is the teachers' lack of experience in developing courses (Hubackova and Semradova, 2016). This investigation proves the importance of budgeting for the integration of blended learning technologies, teachers' training, involvement of technical and professional specialists in the process of organizing technology-based learning (Wen and Zhang, 2020).

Blended learning technologies provide a higher level of self-organization of students' individual work, and in some cases - one hundred percent responsibility for the work performed (Conway et al, 2011; Chaikin and Kirieieva, 2020). Groups of students move from personal communication to asymmetric work in the process of integrating blended learning. Technology is an effective tool for exchange and communication (Conway et al, 2011). Blended learning gradually reduces the role of the teacher as an organizer of the process of learning foreign languages: the teacher answers questions, provides tasks, solves problems. This has ensured a higher level of teachers' involvement (Koch, 2020). Blended learning ensures the development of students' social and communication skills; it develops the ability to effectively interact and exchange for solving common problems (Shaidullin et al, 2014; Karimova and Zhetpeisova, 2020). Along with this, the role of the teacher is mixed from the subject of information and knowledge transfer to the mentor, with an emphasis on the student as a key subject of the educational process. Such a studentcentered approach increases the level of motivation of all interested parties: the teacher feels more needed, especially when problems arise, the student becomes more organized and responsible, as well as independent. Similar findings are contained in studies of C. Banditvilai (2016) and M.V. Arkhipova, E.E. Belova, Y.A. Gavrikova, N.A. Lyulyaeva, E.D. Shapiro (2017); the scholars highlight the increase in the level of motivation to learn foreign languages in the process of using blended learning technologies. 


\section{CONCLUSIONS}

The conducted study makes it possible to draw a number of important conclusions. Firstly, the socialdemographic characteristics of students affect the efficiency of self-organization of students' work when studying foreign languages with application of technology. This requires the development of video instructions for the use of blended learning technologies. Age, gender and course of study determine the level of autonomy that should be taken into account in the development of blended learning programs. Secondly, the basic problems of individual work of students in blended learning of foreign languages at HEI are determined as follows: technical ones and the need for support from a technical specialist; inconvenience of a blended learning system; the need for additional technical skills; the complexity of blended learning. Along with this, the main advantages of students are the potential of using blended learning, ease of use, successful integration of different functions and their interaction; speed of learning in the use of blended learning technologies. Thirdly, the effectiveness of the learning process based on the system and technologies of blended learning is also assessed at the average level. Among the biggest problems the following ones should be noted, namely: unclear goals of using the blended learning system; organization of the blended learning process; ease and simplicity of presentation of the material; lack of examples and illustrative material; lack of time to study materials; expansion of professional and communication skills.

The basic prospects for improving autonomous learning and improving the efficiency of individual work of students in blended learning of foreign languages at higher educational institutions are improving the main areas of development of blended courses. These directions include interaction, research, task and tool development, materials, integration, assessment, context, teachers' training, students' learning.

\section{REFERENCES}

Arkhipova, M.V., Belova, E.E., Gavrikova, Y.A., Lyulyaeva, N.A., \& Shapiro, E.D. (2017). Blended learning in teaching EFL to different age groups. In International Conference on Humans as an Object of Study by Modern Science (pp. 380-386). Cham: Springer.

Banditvilai, C. (2016). Enhancing students' language skills through blended learning. Electronic Journal of e-Learning, 14(3), 220-229.

Berzina, D. (2019). Learning by doing. case study: Education for sustainable development at the university of Latvia. Periodicals of Engineering and Natural Sciences, 7(1), 156-164.

Bodnar, T.O. (2021). Motivational components of a blended learning system for teachers and students. Scientific Bulletin of Mukachevo State University. Series "Pedagogy and Psychology", 7(1), 3643.

Buran, A., \& Evseeva, A. (2015). Prospects of blended learning implementation at technical university. Procedia-Social and Behavioral Sciences, 206, 177-182.

Chaikin, O., \& Kirieieva, E. (2020). Branch approach to sustainable development and inclusive growth: Ukraine case. Scientific Horizons, 6(91), 19V25.

Conway, M., Poutanen, P., Parviainen, O., \& Åberg, L. (2011). Conditions for self-organizing and creativity in blended learning environments. On the Horizon, 19(4), 286-296.

Frankl, G., \& Bitter, S. (2011). Blended learning at the Alpen-Adria-Universität Klagenfurt. In 14th International Conference on Interactive Collaborative Learning (pp. 492-497). Piscataway: IEEE.

Grasl, M.C., Pokieser, P., Gleiss, A., Brandstaetter, J., Sigmund, T., Erovic, B.M., \& Fischer, M.R. (2012). A new blended learning concept for medical students in otolaryngology. Archives of Otolaryngology-Head \& Neck Surgery, 138(4), 358-366.

Hockly, N. (2018). Blended learning. ELT Journal, 72(1), 97-101.

Holiachuk, N., Volot, O., \& Holiachuk, S. (2020). Accounting and analytical aspects of the efficiency of using equity. Scientific Horizons, 23(11), 61-69. 
Hryniak, A.B., Pleniuk, M.D., \& Lapko, A.H. (2021). Practical-oriented nature of learning as an important component of legal education reform in Ukraine. Journal of the National Academy of Legal Sciences of Ukraine, 28(3), 186-196.

Hubackova, S., \& Semradova, I. (2016). Evaluation of blended learning. Procedia-Social and Behavioral Sciences, 217, 551-557.

$\mathrm{Ju}, \mathrm{S} . Y$. (2018). Perceptions and practices of blended learning in foreign language teaching at USIM. European Journal of Social Sciences Education and Research, 12(1), 170-176.

Karimova, B.S., \& Zhetpeisova, N.O. (2020). On innovative pedagogical technologies and training methods. International Journal of Learning and Change, 12(1), 15-24.

Koch, L.T. (2020). Constraints of reflection in foreign language learning. Philologia Hispalensis, 1(34), 63-78.

Lopukhova, J., Makeeva, E., \& Rudneva, T. (2019). Using flipped classroom in foreign language teaching: Implementation of interactive educational technologies. In International Conference on Interactive Collaborative Learning (pp. 619-630). Cham: Springer.

Motschnig-Pitrik, R., \& Mallich, K. (2004). Effects of person-centered attitudes on professional and social competence in a blended learning paradigm. Educational Technology \& Society, 7(4), 176192.

Nazarenko, A.L. (2015). Blended learning vs traditional learning: What works? (A case study research). Procedia-Social and Behavioral Sciences, 200, 77-82.

Pohrishchuk, H.B., \& Voloshchuk, R.Ye. (2021). Content and functional purpose of the duty in modern conditions. Scientific Bulletin of Mukachevo State University. Series "Economics", 8(3), 123133.

Sanjeev, R., \& Natrajan, N.S. (2019). Role of blended learning environment towards student performance in higher education: Mediating effect of student engagement. International Journal of Learning and Change, 11(2), 95-110.

Saray, S., Satir, T., \& Dogan-Saglamtimur, N. (2021). Proficiency of Maritime English course: An investigation in Istanbul, Turkey. Heritage and Sustainable Development, 3(1), 6-15.

Schober, B., Wagner, P., Reimann, R., \& Spiel, C. (2008). Vienna E-Lecturing (VEL): Learning how to learn self-regulated in an Internet-based blended learning setting. International Journal on Elearning, 7(4), 703-723.

Senne, F., Portilho, L., Storino, F., \& Barbosa, A. (2020). Unequal inclusion: An analysis of the trajectory of inequalities in access, use and appropriation of the internet in brazil. Revista De Direito, Estado e Telecomunicacoes, 12(2), 187-211.

Shaidullin, R.N., Safiullin, L.N., Gafurov, I.R., \& Safiullin, N.Z. (2014). Blended learning: Leading modern educational technologies. Procedia-Social and Behavioral Sciences, 131, 105-110.

Temelman-Yogev, L., Katzir, T., \& Prior, A. (2020). Monitoring comprehension in a foreign language: Trait or skill? Metacognition and Learning, 15(3), 343-365.

Tomlinson, B., \& Whittaker, C. (2013). Blended learning in English language teaching. London: British Council.

Voitsikhovskyi, A., Bakumov, O., Ustymenko, O., \& Syroid, T. (2021). The right of access to the internet as fundamental human right given the development of global information society. Revista De Direito, Estado e Telecomunicacoes, 13(1), 1-19.

Waitzman, R., Knobler, H.Y., \& Jaffe, E. (2019). Interpersonal communication barriers in religiously diverse emergency medical teams. Medicine and Law, 38(4), 667-676.

Wan, S., \& Niu, Z. (2018). An e-learning recommendation approach based on the self-organization of learning resource. Knowledge-Based Systems, 160, 71-87.

Wang, Y., Han, X., \& Yang, J. (2015). Revisiting the blended learning literature: Using a complex adaptive systems framework. Journal of Educational Technology \& Society, 18(2), 380-393.

Wen, Q., \& Zhang, H. (2020). Building professional learning communities of foreign language teachers in higher education. Circulo de Linguistica Aplicada a la Comunicacion, 84, 1-12. 